\title{
Tokyo Hosts First MRS International Meeting on Advanced Materials
}

The first MRS International Meeting on Advanced Materials will be held in Tokyo, Japan, May 30-June 3, 1988. Twenty technical symposia plus a tutorial symposium on Frontiers in Materials Science and Engineering will focus on the advanced materials that play key roles in present and future industry. Both invited and contributed papers will cover topics in an interdisciplinary manner detailing all relevant aspects, including physics, chemistry, mechanical and electromagnetic properties, production technology, and possible applications. Highlights of the symposia are described below.

Special events planned for the meeting include the following: a speaking contest for young scientists and engineers beginning Sunday morning, May 29; a welcome reception for meeting participants on Monday evening, May 30; and a banquet on Wednesday evening, June 1. A special event immediately preceding the meeting is the ' 88 Advanced Materials and Engineering Exhibition, May 27-30, at the Tokyo Internation Trade Fair Grounds (Harumi). Over 150,000 people are expected to attend this major exposition of new materials and equipment. Be sure to visit the MRS Booth there.

\section{Symposium A-Composites \\ May 31-June 3}

Approximately 50 invited and contributed papers will cover fabrication, testing and evaluation of metal matrix composites, properties of metal matrix composites, fabrication and properties of ceramic matrix composites, and fibers, films and applications. Invited speakers include: $W$. C. Harrigan, D.B. Marshall, M. Van de Voorde.

\section{Symposium B-Rapid Quenching June 2-3}

Approximately 30 invited and contributed papers will cover amorphous and crystalline alloys, ceramics ar.d metastable crystalline alloys. Approximately 30 poster papers will deal with amorphous, quasicrystalline and metastable crystalline alloys, and ceramics. Invited speakers include: A. Inoue, H.S. Chen, T. Sato, K. Hirao, L. Arnberg, L.E: Hackman, E.N. Kaufmann, K.V. Rao, and S.K. Das.

\section{Symposium C-Powder Preparation} June 1-3

Approximately 36 invited and contributed papers will describe powder preparation (by atomization, plasma and other processes and from metal alkoxides and organic and inorganic compounds), powder processing and characterization, and powder preparation from solution and by spraying. Invited speakers include: A. Lawley, M.J. Cima, G.J. Vogt, R.W. Siegel, J.H. Adair.

\section{Symposium D-Superconductivity May 31-June 3}

The final program will be announced separately at a later date. Approximately 135 contributed and invited papers have already been scheduled to detail various aspects of high temperature superconductivity, including oxide and metal superconductors, theory, physical properties, processing, thin films and devices. Three poster sessions have also been scheduled. Invited speakers include: S. Tanaka, A.V. Sleight, Lin Li, E.M. Engler, M. Suzuki, H. Itozake, A.I. Braginski, Y. Tarutani, K. Wasa, H. Bando, K. Yamanaka, D.V. Johnson Jr., Y. Tanaka, Y Muto, K. Yoshizaki, H.W. Weber, K. Togano, H. Fukuyama, K. Kitazawa, J.V. Ekin, H. Maeda, M. Suenaga, Y. Kubo, D. V. Capone, S. Sakka, H.C. Freyhardt, Y. Nishihara.

\section{Symposium E-Superplasticity May 31-June 1}

Approximately 40 invited and contributed papers will investigate the development, behavior, characteristics, enhancement, and mechanisms of superplasticity of metals, alloys and advanced ceramics. Invited speakers include: $\mathrm{N}$. Ridley, C.H. Hamilton, C. Carry, R. Raj, IW. Chen.

\section{Symposium F-Joining of Metals and Ceramics \\ June 2-3}

Approximately 45 invited, contributed and poster papers will be devoted to understanding the fundamental aspects of the joining dissimilar and similar materials, with an emphasis on ceramics. Aspects to be discussed include structures, filler materials, mechanical properties and processes. Invited speakers include: R.E. Loehman, M.G. Nicholas, A.J. Moorhead, Y. Ishida, R. Yamamoto, $\mathrm{H}$. Fischmeister.

\section{Symposium G-Corrosion/Coating of Advanced Materials \\ June 2-3}

Approximately 49 invited, contributed and poster papers will be presented in sessions on hot gas corrosion and molten and liquid corrosion of ceramics, molten and liquid corrosion of alloys, and high temperature oxidation and corrosion of alloys. Invited speakers include: M. Yoshi- mura, F. Thummler, M. Van de Voorde, $Y$. Saito, J. Stringer, R.A. Rapp.

\author{
Symposium H-Shape Memory \\ Materials \\ May 31-June 3
}

Approximately 50 invited and contributed papers and 45 poster papers will consider shape memory materials with special emphasis on new materials and potential applications. Scheduled sessions will cover the mechanism of martensitic transformations and lattice instability, ferrous alloys, Ti-Ni alloys, copper and other alloys, and other materials. Invited speakers include: $G$. Shirane, T. Suzuki, T. Maki, A. Sato, C.M. Wayman, T. Saburi, K. Uchino, T. Sakuma, W. Yening, L. Delaey, T. Tadaki, Y Suzuki, C. Youyi, T.W. Duerig.

\section{Symposium I-Hydrogen Absorbing Materials \\ June 2-3}

Approximately 24 invited and contributed papers are scheduled in sessions on the properties, structural properties, electronic properties and applications of metal hydrides. Invited speakers include: L. Schlapbach, D. Noreus, K. Yvon, M. Gupta, T. Sakai.

\section{Symposium J-Structural Ceramics June 2-3}

Approximately 36 invited and contributed papers will detail mechanical properties, processing (silicon nitride, zirconia, carbides, borides), machining, and the current status of structural ceramics, their applications and design. A joint session is planned with Symposium M. Invited speakers include: T. Nakagawa, M. Mizukane, J.L. Mason, Y. Hamano, R. Kamo, H. Kawamura, E.J. Lenoe.

\section{Symposium K-Multilayers May 31-June 3}

Approximately 79 invited and contributed papers will discuss procesing, characterization and applications of multilayers mainly composed of metals and ceramics. Session topics include superconductivity and transport phenomena, ceramic superlattices, ceramic devices and packages, mirrors, magnetism and magnetic materials, interfaces and diffusion, and structure and crystal growth. Invited speakers include: H. Fujimore, Y. Bando, Y. Sakabe, E.A. Kemp, N. Kitahara, A. Horiguchi, C.M. Falco, K. Yamashita, G. Guntherodt, C.P. Flynn, T. Katayama, T. Shinjo, N.S. Kazama, H. 
Sakakima, M. Naoe, H. Nakajima, I. Ohdomari, C.V. Thompson, E. Bauer, N. Nakayama, Y. Ishida, C. Uher.

\section{Symposium L-Microstructure-Property} Relationships in Magnetic Materials May 31-June 1

Approximately 26 invited and contributed papers will address the goal of unraveling microstructure-property relationships in magnetic materials, covering such areas as soft and hard magnetic materials, magnetic recording media and magneto-optical recording media. Invited speakers include: $\mathrm{H}$. Kronmuller, $\mathrm{S}$. Hirosawa, G. Thomas, M. Tokunaga, $K$. Goto, T. Umeda, M. Okada, Y. Sakamoto, T. Nozawa, K.I. Arai, Y. Takada, M. Takahashi, T. Nomura, T. Fujiwara, E.E. Marinero, K. Fukamichi.

\section{Symposium M-Fracture Mechanics May 31-June 1}

Approximately 41 invited, contributed and poster papers will concentrate on the mechanisms, evaluation and analysis of toughness and toughening, fracture of rocks and concretes, composites, and metals and alloys. A joint session is planned with Symposium M. Invited speakers include: R.M. McMeeking, Y-W. Mai, V.C. Li, D.B. Marshall, D. Munz.

\section{Symposium N-Biomaterials June 2-3}

Approximately 22 invited and contributed papers will consider hydroxyapatite ceramics and coated materials, titanium implants, Mg-PSZ and alumina in bioactive media, other materials, and methods of evaluating the biological properties of nondirect-contact blood. Invited speakers include: C. Lorprayoon, M.V. Swain, E. Dorre, X. Miao.

\section{Symposium O-Catalytic Materials May 31-June 1}

Approximately 30 invited and contributed papers will new developments of advanced materials for catalysts in sessions on zeolites and layered compounds, catalytic combustion, multicomponent metal oxides, supported metals, sensors, and new applications. Invited speakers include: Y. Ono, S-I. Woo, E. Kikuchi, D.E.W. Vaughn, A. Kato, H. Arai, K. Sato, T. Inui, M. Misono, R.A. Huggins, B.C.H. Steele, A.W. Sleight, W.E. Brower Jr., A. Ueno.

\section{Symposium P-Ionic Polymers}

May 31-June 1

Approximately 24 invited and contributed papers will focus on understanding the trends and latest research on ionic polymers in sessions on polyelectrolyte complexes, electronic properties, functional gels, polymer-metal complexes, charged matrices, and biological applications. Invited speakers include: A. Eisenberg, E.A. Bekturov, Y. Okamoto, S.C. Kim, A.D. Wilson.

\section{Symposium Q-Ordered Polymers for High Performance Materials \\ May 31-June 1}

Approximately 28 invited and contributed papers will highlight current scientific and technological issues related to ordered polymers in sessions on Langmuir-Blodgett polymers, liquid crystalline polymers, high strength and high modulus polymers, electrically conductive polymers, permselective polymeric membranes, control of higher order structure by processing, and polymer alloys. Invited speakers include: J.B. Lando, J. Economy, R.S. Porter, T. Hashimoto.

\section{Symposium R-Photoresponsive \\ Materials \\ May 31-June 2}

Approximately 36 invited and contributed papers and 40 poster papers will deal with current problems of photoresponsive materials in sessions on nonlinear optical materials, photochemical hole burning, catalysis, photochromism, photoresponse, photoenergy and photoresist. Invited speakers include: J. Zyss, S. Miyata, J.L. Bredas, T.J. Twieg, G.R. Meredith, A.F. Garito, S. Saikan, K. Honda, T.A. Skotheim, R. Potember, A. Heller, M.M. Shahin, Y. Yamoka, K.P. Jaeckel.

Symposium S-Advanced Cements and Chemically Bonded Ceramics May 31-June 1

Approximately 29 invited and contributed papers will focus on recent advances in both science and application, covering such areas as composites with polymers, phosphates, macro-defect-free cement, fine particles, composites with fibers, and special cements. Invited speakers include: Y. Ohama, M. Kawakami, D.M. Roy, H. Monma, S. Nagataki, J.D. Birchall, S. Akihama, F.P. Glasser.

\section{Symposium T-Biosensors}

May 31-June 1

Approximately 32 invited, contributed and poster papers will summarize the status of such areas as enzyme sensors, biosensors for clinical analyses, microbiosensors, and novel biosensors. Invited speakers include: M. Mascini, R. Schmid, M. Totani, C.C. Liu, A. Heller, Y. Umezawa, M. Aizawa.

\section{Symposium X-Frontiers of Materials Science and Engineering}

Invited speakers will present a series of authoritative reviews for nonspecialists in frontier areas of materials science and engineering. Program to be announced.

\section{For information, contact:}

Profs. M. Doyama or S. Sōmiya c/o Nikkan Kogyo Shimbun, Ltd., Planning Bureau

8-10, Kudan Kita 1-chome, Chiyoda-ku

Tokyo 102, Japan

Telephone: 03-263-2311

Fax: 03-221-7137

Telex: NIKKANKO J29687

\section{For registration and hotel information, contact:}
Materials Research Society
9800 McKnight Road, Suite 327
Pittsburgh, PA 15237
Telephone (412) 367-3036
$\operatorname{Fax}(412) 367-4373$ 